\title{
PEMANFAATAN LIMBAH BULU AYAM MENJADI BAHAN PAKAN IKAN DENGAN FERMENTASI Bacillus subtilis \\ (Utilization of Waste Chicken Feather to Fish Feed Ingredients Material with Fermentation of Bacillus subtilis)
}

\author{
Dini Siswani Mulia*, Risna Tri Yuliningsih, Heri Maryanto dan Cahyono Purbomartono \\ Program Studi Pendidikan Biologi, Fakultas Keguruan dan Ilmu Pendidikan, \\ Universitas Muhammadiyah Purwokerto, Jl. Raya Dukuh Waluh PO Box 202 Purwokerto 53182. \\ *Penulis korespondensi. Tel: 0281-636751. Email: dinisiswanimulia@ump.ac.id.
}

Diterima: 14 Juli 2015

Disetujui: 12 November 2015

\begin{abstract}
Abstrak
Penelitian ini bertujuan untuk memanfaatkan limbah bulu ayam menjadi bahan pakan ikan dengan fermentasi Bacillus subtilis. Penelitian menggunakan metode eksperimen dengan Rancangan Acak Lengkap (RAL) 4 perlakuan, 3 kali ulangan, yaitu P0 : tepung bulu ayam non fermentasi; P1 : fermentasi dengan inokulum B. subtilis $5 \mathrm{~mL} / 2 \mathrm{~g}$ tepung bulu ayam; P2 : fermentasi dengan inokulum $B$. subtilis $10 \mathrm{~mL} / 2 \mathrm{~g}$ tepung bulu ayam; P3 : fermentasi dengan inokulum B. subtilis $15 \mathrm{~mL} / 2$ g tepung bulu ayam. Parameter yang diamati adalah hasil uji proksimat meliputi kadar protein kasar, kadar air, kadar abu, kadar lemak kasar, kadar serat kasar, dan parameter pendukung yaitu uji organoleptik, berupa sifat fisik tepung bulu ayam, meliputi warna, tekstur, dan bau. Data berupa hasil uji proksimat dianalisis menggunakan ANAVA dan Duncan Multiple Range Test (DMRT) dengan taraf uji 5\%, sedangkan untuk data hasil organoleptik dianalisis secara deskriptif kualitatif. Hasil penelitian menunjukkan bahwa pemanfaatan limbah bulu ayam menjadi bahan pakan ikan dapat dilakukan dengan fermentasi B. subtilis. Fermentasi tepung bulu ayam menggunakan B. subtillis dapat meningkatkan kualitas bahan baku pakan ikan. Perlakuan P2 (inokulum $10 \mathrm{~mL} / 2 \mathrm{~g}$ tepung bulu ayam) adalah perlakuan yang paling efektif karena menghasilkan protein tertinggi yaitu 80,59\%, dengan perubahan sifat fisik menjadi putih sampai putih kekuningan (warna), lembut (tekstur), dan khas kurang menyengat (bau).
\end{abstract}

Kata kunci: Bacillus subtilis, bahan pakan ikan, bulu ayam, fermentasi, limbah, pemanfaatan.

\begin{abstract}
This study aims to utilize waste chicken feathers into fish feed ingredients by fermentation of Bacillus subtilis. The research has done by experimental methods with completely randomized design (CRD) 4 treatments, 3 repetitions, ie P0: non-fermented chicken feather meal; P1: fermentation with B. subtilis $5 \mathrm{~mL}$ inoculum/2 g chicken feather meal; P2: 10 mL/2 g chicken feather meal; P3: $15 \mathrm{~mL} / 2 \mathrm{~g}$ chicken feather meal. Parameters measured were the proximate test results include the levels of crude protein, moisture, ash, crude fat content, fiber content, and organoleptic parameters that support, in the form of physical properties of chicken feather meal, including color, texture, and smell. Proximate test data were analyzed using Analysis of Variance (ANOVA) and Duncan Multiple Range Test (DMRT) with 5\% level, while the organoleptic data were analyzed qualitatively descriptively. The results showed that the utilization of waste chicken feathers into fish feed ingredients can be done by fermentation of B. subtilis. Fermentation chicken feather meal using inoculum B. subtillis can improve the quality of fish feed ingredients. Treatment P2 (inoculum $10 \mathrm{~mL} / 2 \mathrm{~g}$ chicken feather meal) is the most effective treatment because it produces the highest protein is $80.59 \%$, with changes in physical properties to be white to yellowish white (colour), soft (texture), and less typical sting (smell).
\end{abstract}

Keywords: Bacillus subtilis, fish feed ingredients, chicken feathers, fermentation, waste, utilization.

\section{PENDAHULUAN}

Kegiatan melestarikan dan menjaga lingkungan sebagai bentuk kesadaran terhadap pentingnya mewujudkan lingkungan yang sehat, terus digalakkan. Namun di sisi lain, banyak faktor yang dapat merusak atau mencemari lingkungan, seperti limbah. Tak dapat dipungkiri, peningkatan unit usaha di berbagai bidang, menyisakan limbah yang dapat menjadi sumber masalah. Apabila dibiarkan, limbah dapat menyebabkan pencemaran lingkungan. Pencemaran lingkungan merupakan suatu permasalahan yang sangat global sehingga memerlukan penanganan yang serius, efektif, dan efisien.

Salah satu limbah yang kini banyak ditemui adalah bulu ayam, berupa limbah yang banyak dihasilkan dari industri Rumah Pemotongan Ayam (RPA). Saat ini, banyak bermunculan industri peternakan ayam sebagai dampak positif dari peningkatan permintaan konsumen terhadap daging ayam. Peningkatan industri peternakan ayam turut mendongkrak usaha pemotongan ayam yang berdampak pada peningkatan limbah industri berupa 
bulu ayam. Anonim (2012) melaporkan bahwa populasi ayam pedaging di Provinsi Jawa Tengah sebanyak 55.621.113 ekor. Populasi ayam pedaging berbanding lurus dengan jumlah limbah yang dihasilkan oleh RPA yang salah satunya berupa bulu ayam. Sekitar 4-5\% dari bobot hidup ayam pedaging adalah bulu dan rata-rata bobot panennya sebesar 1,6 kg (Sa'adah dkk., 2013).

Limbah bulu ayam yang tidak dimanfaatkan dan dibuang begitu saja di lingkungan sekitar RPA dapat menimbulkan bau yang tidak sedap. Selain itu, menjadi tempat bersarangnya penyakit, dan biasanya sangat mengganggu kesehatan manusia (Periasamy dan Subash, 2004). Dampak lain, yaitu dapat menurunkan kualitas tanah karena limbah bulu ayam sangat sulit terdegradasi di lingkungan atau proses dekomposernya memakan waktu yang cukup lama. Hal ini dikarenakan sebagian besar proteinnya berupa keratin atau protein fibrous berupa serat. Keratin adalah produk pengerasan jaringan epidermal tubuh seperti kuku, rambut, dan bulu yang tersusun atas protein serat (fibrous) yang kaya akan sistein dan sistin (Suntornsuk dkk., 2005; Sinoy dkk., 2011). Oleh sebab itu, limbah bulu ayam resisten terhadap perombakan atau degradasi dan merupakan masalah serius di lingkungan (Savitha dkk., 2007). Berdasarkan kondisi tersebut, diperlukan pengelolaan dan penanganan limbah yang juga merupakan kebijakan pemerintah dalam melestarikan fungsi lingkungan hidup, seperti yang tercantum dalam Undang - Undang Dasar Republik Indonesia Nomor 23 tahun 1997 tentang Pengelolaan Lingkungan Hidup, yaitu upaya terpadu untuk melestarikan fungsi yang meliputi kebijakan penataan, pemanfaatan, pemeliharaan, pemulihan, pengawasan, dan pengendalian lingkungan hidup (Anonim, 2012).

Dalam pengelolaan limbah, perlu diterapkan teknologi berwawasan lingkungan yang dapat mengatasi permasalahan lingkungan dengan melestarikan fungsi lingkungan. Pelestarian fungsi lingkungan dapat dilakukan dengan prinsip zero waste, yaitu mengurangi atau meminimalisasi pencemaran lingkungan dengan cara pemanfaatan limbah. Limbah bulu ayam telah dimanfaatkan dengan diolah sebagai pupuk dan kerajinan kemoceng (Abubakar dkk., 2000). Ada juga yang memanfaatkan sebagai bahan shuttle cock dan lukisan. Bulu ayam berpotensi untuk dimanfaatkan sebagai pakan ternak (Supriyati dkk., 2000) karena memiliki kandungan protein yang tinggi, yaitu 8090\% dari bahan kering, melebihi kandungan protein kasar bungkil kedelai (42,5\%) dan tepung ikan (66,5\%) (Adiati dan Puastuti, 2004). Komposisi kimia tepung bulu ayam yang belum difermentasi adalah $81 \%$ protein, 1,2\% lemak, $86 \%$ bahan kering, dan 1,3\% abu (Zerdani dkk., 2004), selain itu juga tepung bulu ayam mengandung mineral kalsium $0,19 \%$, fosfor $0,04 \%$, kalium $0,15 \%$ dan sodium 0,15\% (Kim dan Patterson, 2000). Berdasarkan kandungan gizinya, bulu ayam dapat dijadikan pakan hewan, salah satunya sebagai bahan pakan ikan (Imansyah, 2006). Penyusunan formulasi pakan ikan harus memperhatikan nutrisi yang diperlukan ikan pada umumnya, yaitu protein, karbohidrat, lemak, mineral, dan vitamin (Agustono dkk., 2007).

Meskipun kandungan protein tinggi, tetapi protein bulu ayam merupakan jenis protein yang sulit dicerna, karena tergolong jenis protein keratin (Joshi dkk., 2007). Keratin merupakan produk pengerasan jaringan epidermal tubuh seperti kuku, rambut, dan bulu yang tersusun atas protein serat (fibrous) yang kaya akan sistein dan sistin (Sinoy dkk., 2011). Di samping itu, keratin tersusun atas 14\% ikatan disulfida sehingga menjadi sangat stabil, kaku, dan tidak dapat dicerna dengan baik oleh enzim proteolitik seperti tripsin, pepsin, dan papain yang terdapat dalam organ pencernaan (Brandelli, 2008; Mazotto dkk., 2011). Daya cerna protein keratin bulu ayam dalam organ pencernaan hewan ruminansia hanya sebesar 5,8\% (Achmad, 2001). Daya cerna protein yang rendah tersebut menjadi satu kendala untuk menjadikan bulu ayam sebagai sumber protein pakan ikan. Oleh karena itu, untuk meningkatkan kualitas bulu ayam, terlebih dahulu akan dijadikan tepung bulu ayam selanjutnya difermentasi.

Fermentasi umumnya dilakukan oleh mikrooganisme. Mikroorganisme pendegradasi keratin di antaranya adalah jenis bakteri Bacillus sp. (Tiwary dan Gupta, 2012). Salah satu bakteri yang dapat mendegradasi keratin adalah bakteri $B$. subtilis (Madigan, dan Martinko, 2005). Bakteri B. subtillis memiliki kemampuan mendegradasi keratin yang terdapat pada bulu ayam karena terdapat enzim keratinolitik yang dihasilkan. Fermentasi yang dilakukan oleh inokulum Bacillus sp. mampu meningkatkan daya cerna dan mempengaruhi kualitas protein. Wulandari dkk. (2013) menyatakan bahwa teknik hidrolisis secara fisikokimia dan biologi mampu meningkatkan daya cerna tepung bulu ayam. Fermentasi pada dasarnya memperbanyak mikroorganisme yang menghasilkan enzim yang dapat merombak bahan yang sulit dicerna menjadi mudah dicerna sehingga dapat memperbaiki kualitas pakan, dan menambah aroma atau flavor (Sefrita, 2008).

Keratinase mempunyai kemampuan yang sangat baik dalam menurunkan kadar keratin melalui perombakkan struktur jaringan kimia dinding sel, pemutusan ikatan hidrogen, dan ikatan disulfida penyusun keratin (Rodriguez dkk., 2009). Penelitian menggunakan bakteri Bacillus sp. dalam fermentasi bulu ayam pernah dilakukan oleh Desi (2002) 
dengan menggunakan spesies $B$. licheniformis. Hasilnya menunjukkan bahwa setelah dilakukan fermentasi, kadar protein kasar pada bulu ayam meningkat dari 95,17\% menjadi 97,12\% menggunakan inokulum sebanyak $10 \mathrm{~mL} / 2 \mathrm{~g}$ tepung bulu ayam.

Berdasarkan hasil penelitian sebelumnya, diduga penggunaan jenis bakteri dengan jumlah inokulum yang digunakan dalam fermentasi masih perlu diteliti lagi sehingga dapat diperoleh peningkatan kadar protein kasar yang optimum dan baik digunakan untuk meningkatkan kualitas pakan ikan. Dalam penelitian ini, limbah bulu ayam akan difermentasi dengan $B$. subtilis dengan jumlah inokulum 5 , 10, dan $15 \mathrm{~mL} / 2 \mathrm{~g}$ tepung bulu ayam, untuk mengkaji perbandingan yang paling baik dalam meningkatkan kualitas bahan pakan ikan. Jumlah inokulum didasarkan pada penelitian Desi (2002) yang menggunakan $10 \mathrm{~mL} / 2 \mathrm{~g}$ tepung bulu ayam. Penelitian ini bertujuan untuk memanfaatkan limbah bulu ayam menjadi bahan pakan ikan dengan fermentasi B. subtilis.

\section{METODE PENELITIAN}

\section{Alat dan Bahan}

Peralatan yang digunakan dalam penelitian ini, meliputi mesin penggilingan, wadah plastik, ember, kantong plastik, cawan petri, jarum ose, drugalsky, bunsen, sprayer, $\mathrm{pH}$ meter, Laminar Air Flow (LAF), autoklaf, inkubator, timbangan analitik, tabung reaksi, glass ukur, filler pump, tabung reaksi, mikropipet, kapas, kain kasa, alumunium foil, hot plate, vortex, erlenmeyer, alat destilasi, dan mikro Kjeldahl.

Bahan-bahan yang digunakan dalam penelitian ini meliputi bahan uji dan bahan kimia. Bahan uji yang digunakan adalah bulu ayam yang diperoleh dari limbah RPA Citra yang ada di Desa Dampit, Banyumas, Bakteri B. subtilis, yang diperoleh dari Laboratorium Mikrobiologi, Fakultas Biologi Universitas Jenderal Soedirman. Bahan kimia yang digunakan meliputi media Nutrient Agar (NA), Nutrient Broth (NB), peptone water, aquades, alkohol, larutan $\mathrm{NaCl} \mathrm{0,1} \mathrm{M}$, indikator methyl red brom creosol green dan $\mathrm{H}_{3} \mathrm{BO}_{3}$ (asam borat).

\section{Rancangan Penelitian}

Rancangan penelitian menggunakan rancangan acak lengkap dengan 4 perlakuan dan 3 kali ulangan. Perlakuan antara lain P0 (kontrol, non fermentasi), P1 (fermentasi dengan inokulum $B$. subtilis $5 \mathrm{~mL} / 2$ $\mathrm{g}$ tepung bulu ayam), P2 (fermentasi dengan inokulum $B$. subtilis $10 \mathrm{~mL} / 2 \mathrm{~g}$ tepung bulu ayam), P3 (fermentasi dengan inokulum B. subtilis $15 \mathrm{~mL} / 2$ g tepung bulu ayam).

\section{Prosedur Penelitian \\ Perbanyakan biakan bakteri B. subtilis}

Sebelum dilakukan perbanyakan bakteri, terlebih dahulu dilakukan purifikasi Bakteri $B$. subtillis, dan media yang digunakan adalah media NA. Selanjutnya, dibuat inokulum bakteri tersebut dan ditumbuhkan pada media NA yang dibuat miring pada tabung reaksi dan diinkubasi pada suhu kamar selama 48 jam. Sebanyak $10 \mathrm{~mL}$ NB dimasukkan ke dalam tabung biakan bakteri $B$. subtillis sehingga diperoleh suspensi sel bakteri yang disebut dengan inokulum (Desi, 2002).

Perbanyakan $B$. subtilis dilakukan dengan menginokulasi biakan pada media NA dan diinkubasi selama 48 jam. Isolat dipindahkan ke dalam $10 \mathrm{~mL}$ media NB dan diinkubasi pada pH 8,0 dan suhu $45^{\circ} \mathrm{C}$ selama 5 hari. Kultur yang dihasilkan dipindahkan seluruhnya ke dalam $90 \mathrm{~mL}$ media NB dan diinkubasi selama 48 jam. Seluruh kultur dipindahkan ke dalam $900 \mathrm{~mL}$ media NB dan diinkubasi kembali selama 48 jam. Hasil akhir dari proses ini diperoleh kultur bakteri $B$. subtilis yang digunakan untuk proses fermentasi sebanyak 1000 $\mathrm{mL}$ (Desi, 2002).

Konsentrasi $B$. subtilis dihitung dengan cara pengenceran. Sebanyak $1 \mathrm{~mL}$ kultur diencerkan dalam beberapa kali tingkat pengenceran. Pengenceran dilakukan dengan menggunakan larutan $\mathrm{NaCl}$ 0,1 $\mathrm{M}$ steril. Pada tiga pengenceran terakhir yaitu $10^{-5}, 10^{-6}$, dan $10^{-7}$ masing-masing diambil $1 \mathrm{~mL}$ dan dituangkan pada cawan petri steril. Medium NA ditambahkan ke dalam cawan petri dan dibiarkan selama 2x24 jam. Penghitungan jumlah koloni dilakukan dengan menggunakan metode Total Plate Count (TPC) (Desi, 2002).

\section{Pembuatan tepung bulu ayam}

Pembuatan tepung bulu ayam dilakukan dengan cara bulu ayam dikumpulkan dan diambil dari RPA. Bulu ayam yang terkumpul dicuci hingga bersih dengan air mengalir. Hal tersebut dimaksudkan untuk memisahkan bulu ayam dari sisa-sisa darah maupun kotoran lainnya yang menempel. Bulu ayam yang sudah bersih dikeringkan pada sinar matahari hingga benar-benar kering. Bulu ayam yang sudah kering digiling menggunakan mesin giling (Tarmizi, 2001).

\section{Fermentasi tepung bulu ayam}

Proses fermentasi dilakukan dengan terlebih dahulu melakukan sterilisasi tepung bulu ayam pada $121{ }^{\circ} \mathrm{C}, 1 \mathrm{~kg} / \mathrm{cm}^{2}$ selama 15 menit dengan tujuan untuk menghilangkan mikroorganisme ikutan atau mencegah terjadinya kontaminan oleh mikroorganisme lain. Sebanyak $2 \mathrm{~g}$ tepung bulu ayam dicampurkan dengan masing-masing inokulum cair B. subtilis sebanyak 5, 10, dan $15 \mathrm{~mL}$ 
ke dalam Erlenmeyer pada $\mathrm{pH}$ 8,5 dan diinkubasi dalam inkubator pada suhu $55^{\circ} \mathrm{C}$ selama 72 jam. Hasil dari proses fermentasi diperoleh tepung bulu ayam yang disebut dengan hidrolisat bulu ayam (HBA) (Desi, 2002).

\section{Parameter penelitian}

Parameter yang diamati adalah uji proksimat terhadap kadar protein kasar, kadar lemak kasar, kadar abu, kadar serat kasar, kadar air dan uji organoleptik pada bulu ayam tanpa fermentasi dan yang difermentasi, meliputi warna, tekstur, dan bau. Data berupa hasil uji proksimat dianalisis menggunakan Analysis of Variance (Anova) dan Duncan Multiple Range Test (DMRT) dengan taraf uji 5\%, sedangkan data hasil organoleptik dianalisis secara deskriptif kualitatif.

\section{HASIL DAN PEMBAHASAN}

Pemanfaatan limbah bulu ayam dilakukan dengan prinsip zero waste dan dimanfaatkan sebagai bahan pakan ikan. Bulu ayam terlebih dahulu dibuat tepung, selanjutnya difermentasi dengan bakteri $B$. subtilis dengan jumlah inokulum berbeda.

\section{Hasil uji proksimat}

Hasil penelitian menunjukkan bahwa perlakuan fermentasi dengan berbagai jumlah inokulum dan non fermentasi berpengaruh nyata terhadap hasil uji proksimat, meliputi kadar protein kasar, kadar lemak kasar, kadar abu, kadar serat kasar, dan kadar air tepung bulu ayam (Tabel 1).

\section{Kadar protein kasar}

Perlakuan non fermentasi (P0) mengandung protein kasar sebesar $73,56 \%$. Kadar protein meningkat setelah tepung bulu ayam difermentasi menggunakan inokulum bakteri $B$. subtilis, P1 sebesar 78,24\%, P2 sebesar 80,50\%, dan P3 sebesar $78,51 \%$. Perlakuan P0 memiliki kadar protein yang paling rendah dibandingkan perlakuan lainnya, karena merupakan tepung bulu ayam tanpa fermentasi, dan perlakuan P2 memiliki kadar protein kasar yang paling tinggi dibandingkan perlakuan lainnya.
Peningkatan kadar protein kasar pada tepung bulu ayam terjadi karena proses fermentasi. Hal ini diduga adanya aktivitas keratinase yang dihasilkan oleh bakteri uji, yaitu B. subtilis. Brandelli (2008) menyatakan bahwa $B$. subtilis mampu memproduksi enzim keratinase dalam jumlah tinggi. Keratinase merupakan enzim protease spesifik yang memiliki kemampuan memecah substrat keratin.

Menurut Rodriguez dkk. (2009) keratinase mempunyai kemampuan yang sangat baik dalam menurunkan kadar keratin melalui perombakan struktur jaringan kimia dinding sel, pemutusan ikatan hidrogen, dan ikatan disulfida penyusun keratin. Ikatan disulfida antar asam amino sistein menyebabkan protein bulu ayam sulit dicerna oleh enzim proteolitik dalam saluran pencernaan sehingga ikatan disulfida harus dilepaskan melalui hidrolisis oleh mikroba. Keratin atau protein serat terdiri dari komponen ikatan sistein disulfida, ikatan hidrogen, dan interaksi hidrofobik molekul keratin (Brandelli, 2008). Ikatan sistein disulfida atau ikatan silang terbentuk antara asam amino sistein yang mengandung gugus $-\mathrm{SH}$. Jika dua unit sistin berikatan, maka terbentuklah sebuah jembatan disulfida_S-S- melalui oksidasi gugus-gugus -SH. Protein serat terbentuk dari molekul yang rapat dan teratur berupa ikatan silang antara rantai-rantai asam amino yang berdekatan sehingga molekul air sulit untuk masuk ke dalam struktur ini, oleh karena itu protein serat tidak larut di dalam air (hidrofobik).

Pada hasil penelitian ini perlakuan P1 dan P2 menunjukkan kadar protein yang tinggi dibandingkan dengan perlakuan yang lain. Hal ini disebabkan karena adanya peningkatan kadar protein kasar pada tepung bulu ayam setelah proses fermentasi disebabkan oleh aktivitas keratinase yang dihasilkan oleh B. subtilis. Sinoy dkk. (2011) menambahkan bahwa enzim keratinase dihasilkan oleh bakteri jenis Bacillus tergolong enzim ekstraseluler. Enzim tersebut mampu menghidrolisis berbagai protein larut dan protein tidak larut seperti protein keratin.

Hasil dari masing-masing perlakuan menunjukkan bahwa peningkatan kadar protein kasar tertinggi dihasilkan oleh perlakuan P2. Kadar protein kasar yang berbeda dari setiap perlakuan

Tabel 1. Hasil uji proksimat tepung bulu ayam non fermentasi dan fermentasi.

\begin{tabular}{lcccccc}
\hline No. & Perlakuan & $\begin{array}{c}\text { Kadar protein } \\
\text { Kasar (\%) }\end{array}$ & $\begin{array}{c}\text { Kadar lemak } \\
\text { Kasar (\%) }\end{array}$ & Kadar abu (\%) & $\begin{array}{c}\text { Kadar serat } \\
\text { Kasar (\%) }\end{array}$ & Kadar air (\%) \\
\hline 1. & P0 & $73,56 \pm 0,32^{\mathrm{a}}$ & $3,37 \pm 0,25^{\mathrm{a}}$ & $1,37 \pm 0,13^{\mathrm{c}}$ & $21,61 \pm 0,19^{\mathrm{b}}$ & $11,69 \pm 0,10^{\mathrm{a}}$ \\
2. & P1 & $79,24 \pm 0,18^{\mathrm{c}}$ & $7,21 \pm 0,48^{\mathrm{b}}$ & $0,51 \pm 0,01^{\mathrm{b}}$ & $0,08 \pm 0,00^{\mathrm{a}}$ & $67,25 \pm 0,72^{\mathrm{b}}$ \\
3. & P2 & $80,59 \pm 0,10^{\mathrm{d}}$ & $10,48 \pm 0,24^{\mathrm{c}}$ & $0,24 \pm 0,25^{\mathrm{a}}$ & $0,05 \pm 0,01^{\mathrm{a}}$ & $68,02 \pm 0,21^{\mathrm{b}}$ \\
4. & P3 & $78,51 \pm 0,40^{\mathrm{b}}$ & $10,39 \pm 0,06^{\mathrm{c}}$ & $0,39 \pm 0,01^{\mathrm{b}}$ & $0,04 \pm 0,00^{\mathrm{a}}$ & $87,55 \pm 0,50^{\mathrm{c}}$ \\
\hline
\end{tabular}

Sumber : Hasil analisis. Keterangan: Huruf superskrip yang berbeda menunjukkan hasil yang berbeda nyata pada uji DMRT dengan taraf uji 5\%, P0 : tepung bulu ayam non fermentasi; P1 : fermentasi dengan inokulum B. subtilis $5 \mathrm{~mL} / 2$ g tepung bulu ayam; P2 : fermentasi dengan inokulum $B$. subtilis $10 \mathrm{~mL} / 2 \mathrm{~g}$ tepung bulu ayam; P3 : fermentasi dengan inokulum $B$. subtilis $15 \mathrm{~mL} / 2 \mathrm{~g}$ tepung bulu ayam. 
diduga karena adanya pengaruh konsentrasi enzim yang dihasilkan oleh bakteri B. subtilis. Perlakuan dengan konsentrasi inokulum $10 \mathrm{~mL}$ menghasilkan kadar protein tertinggi yaitu 80,59\%. Hal tersebut diduga karena konsentrasi enzim pada perlakuan tersebut merupakan kondisi seimbang dengan substrat keratin dalam bulu ayam. Hal tersebut dapat diartikan bahwa antara jumlah inokulum $B$. subtilis dan enzim yang dihasilkan dengan banyaknya subtrat yang tersedia dalam keadaan sebanding sehingga mampu mendegradasi keratin secara optimal dan dapat menghasilkan protein kasar tertinggi dengan peningkatan kadar protein kasar sebesar 7,03\%. Berdasarkan penelitian Desi (2002), penggunaan volume inokulum sebesar $10 \mathrm{~mL}$ dapat menghasilkan peningkatan kadar protein sebesar 2,95\% dari kadar tepung bulu ayam sebelum fermentasi.

Perlakuan P3 menghasilkan kadar protein kasar yang lebih rendah dibandingkan dengan P1 dan P2. Hal tersebut disebabkan karena adanya penurunaan kadar nitrogen akibat terbentuknya gas amoniak dalam proses fermentasi. Hal ini didukung dengan adanya bau yang tidak sedap atau khas (amoniak) yang dihasilkan dari bulu ayam pada perlakuan P3. Adanya $\mathrm{NH}_{3}$ menunjukkan adanya degradasi protein oleh mikroba. Timbulnya aroma atau bau disebabkan karena zat bau yang dihasilkan setelah fermentasi bersifat volatil (mudah menguap) sehingga menimbulkan aroma khas pada bahan (Kumalasari, 2012). Kadar $\mathrm{NH}_{3}$ merupakan petunjuk adanya degradasi protein oleh mikroba. Pada waktu proses fermentasi berlangsung terjadi perubahan protein, lemak, karbohidrat, vitamin, mineral, $\mathrm{pH}$, kelembaban, dan juga aroma dalam bahan (Sonjaya, 2001).

Inokulum dari setiap perlakuan mempengaruhi kadar $\mathrm{NH}_{3}$ yang dihasilkan sehingga berpengaruh terhadap jumlah protein kasar pada bulu ayam. Tinggi rendahnya dosis inokulum mempengaruhi kualitas produk biokonversi. Semakin tinggi dosis inokulum maka semakin banyak enzim yang dihasilkan oleh mikroba, sehingga nutrien yang terurai semakin banyak, termasuk nutrien protein akan lebih banyak terurai menjadi $\mathrm{NH}_{3}$. Pengaruh perbedaan volume inokulum terhadap kadar protein dilaporkan oleh Kumalasari (2012) yang menyatakan bahwa kadar protein menurun dengan semakin banyaknya penambahan inokulum pada fermentasi tempe.

Berdasarkan hasil penelitian dapat disimpulkan bahwa fermentasi dengan bakteri $B$. subtilis dapat memberikan hasil yang nyata terhadap peningkatan kadar protein kasar tepung bulu ayam 73,56\% dan setelah difermentasi meningkat menjadi $80,59 \%$. Jumlah besar volume inokulum bakteri $B$. subtilis yang digunakan dalam fermentasi juga mempengaruhi tingkat kadar protein kasar yang dihasilkan karena semakin besar jumlah inokulum yang digunakan maka kadar protein kasar dapat semakin rendah.

\section{Kadar lemak kasar}

Hasil penelitian menunjukkan bahwa perlakuan fermentasi dan non fermentasi berpengaruh nyata terhadap kadar lemak tepung bulu ayam. P0 memiliki kadar lemak kasar yang paling rendah dibandingkan dengan P1, P2, dan P3. Hal ini dikarenakan lemak kasar adalah zat yang tidak dapat larut dalam air akan tetapi dapat larut dalam pelarut lemak seperti eter, kloroform, dan benzene. Kandungan yang ada pada lemak kasar bukan lemak murni melainkan campuran dari beberapa zat yang terdiri dari klorofil, xantofil, dan karoten. Peningkatan kadar lemak pada perlakuan yang difermentasi, diduga sebagai hasil dari penguraian mikroorganisme (Sonjaya, 2001).

\section{Kadar $a b u$}

Abu adalah zat organik sisa hasil pembakaran suatu bahan organik. Uji kadar abu bertujuan untuk mengetahui kandungan mineral yang terdapat di dalam tepung bulu ayam baik yang difermentasi maupun yang tidak difermentasi. Mineral yang terdapat pada suatu bahan merupakan dua macam garam, yaitu garam organik dan garan anorganik. Garam organik terdiri dari garam-garam asam malat, oksalat, asetat, sedangkan garam anorganik antara lain dalam bentuk garam fosfat, karbonat, sulfat dan nitrat. Kadar abu ditentukan dengan mengoksidasikan semua zat organik pada suhu tinggi, yaitu sekitar $500-600{ }^{\circ} \mathrm{C}$ selama 6 jam dan melakukan penimbangan zat yang tertinggal setelah proses pembakaran tersebut.

P0 memiliki kandungan kadar abu paling tinggi, hal ini disebabkan karena tidak adanya pertumbuhan mikroba di dalamnya. Hal ini didukung oleh pendapat Mildayani dan Haliza (2007) bahwa bahan-bahan organik yang mengalami penurunan selama fermentasi adalah pati dan lemak karena digunakan untuk memenuhi kebutuhan energi pertumbuhan kapang.

Kadar abu pada bulu ayam fermentasi lebih rendah karena seluruh unsur utama pembentuk senyawa organik akan habis terbakar dan berubah menjadi gas, dan sisa unsur yang terbakar adalah abu, yang merupakan kumpulan mineral-mineral. Hal ini didukung oleh pendapat Suparjo (2010), pada suhu tinggi bahan organik yang ada akan terbakar dan sisanya merupakan abu. Kadar abu yang baik sebagai pakan adalah kadar abu yang rendah karena akan mudah untuk dicerna ikan. 


\section{Kadar serat kasar}

Hasil penelitian menunjukkan bahwa P0 berbeda nyata dengan perlakuan fermentasi terhadap kadar serat kasar yang dihasilkan, akan tetapi antara P1, P2, dan P3 masing-masing tidak berbeda nyata (Tabel 1). P0 memiliki kadar serat tepung bulu ayam tertinggi, yaitu 21,61\%, sedangkan tepung bulu ayam fermentasi, yaitu $\mathrm{P} 1$ sebesar 0,08\%, P2 sebesar 0,05\%, dan P3 sebesar 0,04\%. Penurunan serat kasar yang terjadi pada tepung bulu ayam yang difermentasi disebabkan oleh menurunnya serat dalam protein keratin.

Banyaknya serat kasar yang dikandung suatu bahan pakan menyebabkan sel dinding yang kuat dan akibatnya daya cerna pakan menjadi rendah (Wulandari dkk., 2013). Puastuti dkk. (2004) menyatakan bahwa kecernaan bahan kering tepung bulu ayam menunjukkan nilai yang lebih baik setelah dilakukan pemrosesan. Hal ini didukung oleh pernyataan Tillman dkk. (2005) yang menyatakan bahwa kecernaan serat kasar tergantung pada kandungan serat kasar dalam ransum dan jumlah serat kasar yang dikonsumsi. Kadar serat kasar yang terlalu tinggi menyebabkan pencernaan nutrien akan semakin lama dan nilai produktifnya semakin rendah. Daya cerna serat kasar dipengaruhi oleh beberapa faktor antara lain kadar serat dalam pakan, komposisi penyusun serat kasar, dan aktivitas mikroorganisme (Maynard dkk., 2005).

\section{Kadar air}

Tepung bulu ayam non fermentasi (P0) mempunyai kadar air yang rendah yaitu 11,69 \pm

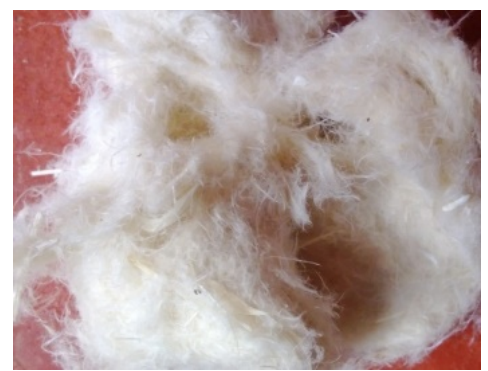

(a)

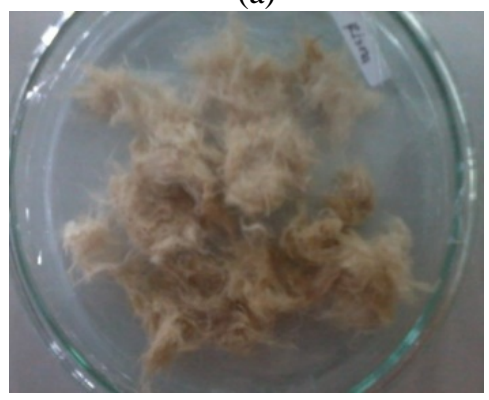

(c)
0,10\%, perlakuan $\mathrm{P} 1$ sebesar 67,25 $\pm 0,72 \%$, perlakuan P2 sebesar 68,02 \pm 0,21\%, dan P3 sebesar $87,55 \pm 0,50 \%$ (Tabel 1). Hasil penelitian menunjukkan bahwa perlakuan berpengaruh nyata terhadap kadar air tepung bulu ayam yang dihasilkan. P0 mempunyai kadar air yang rendah, karena semakin rendah kadar air maka semakin lambat pertumbuhan mikroba. Hal ini sesuai dengan pernyataan Suryono dkk. (2013) bahwa kadar air rendah sangat mempengaruhi keawetan suatu bahan pakan.

P3 memiliki kadar air yang tinggi dari perlakuan lainnya, hal ini terjadi karena selama proses fermentasi terjadi proses metabolisme dan perombakan senyawa makromolekul menjadi senyawa yang lebih sederhana. Metabolisme mikroorganisme umumnya diikuti dengan pelepasan air dan hal ini mengakibatkan naiknya kadar air dari bahan pangan (Buckle, 1987 dalam Kumalasari, 2012). Adanya panas yang dihasilkan oleh proses metabolisme menghasilkan banyak uap air yang terperangkap dalam wadah. Menurut Winarno (2004), kadar air tinggi mempermudah bakteri, kapang, dan khamir untuk berkembang biak, sehingga akan terjadi perubahan pada bahan pangan.

\section{Uji organoleptik}

Uji organoleptik merupakan suatu metode untuk menguji kualitas suatu bahan atau produk menggunakan panca indera manusia. Uji organoleptik dilakukan untuk mengetahui perbedaan fisik yang tampak, meliputi warna, tekstur, dan bau. Morfologi tepung bulu ayam tersaji pada Gambar 1.

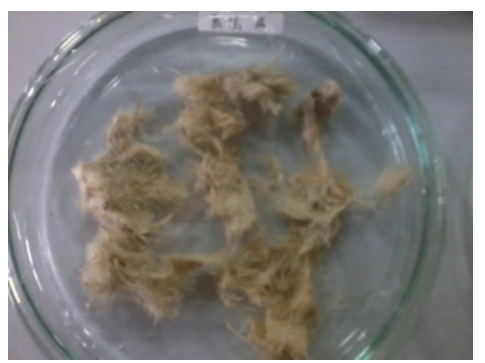

(b)

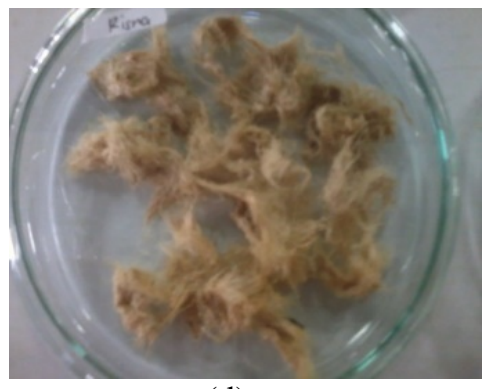

(d)

Gambar 1. Morfologi tepung bulu ayam sebelum dan setelah fementasi dengan berbagai jumlah inokulum. (a) P0 : tepung bulu ayam non fermentasi; (b) P1 : fermentasi dengan inokulum B. subtilis $5 \mathrm{~mL} / 2 \mathrm{~g}$ tepung bulu ayam; (c) P3 : $10 \mathrm{~mL} / 2 \mathrm{~g}$ tepung bulu ayam; (d) P4 : $15 \mathrm{~mL} / 2 \mathrm{~g}$ tepung bulu ayam. 


\section{Warna}

Tepung bulu ayam yang tidak difermentasi berwarna putih tulang, sedangkan yang difermentasi menunjukkan warna yang berbeda-beda, yaitu P1 berwarna putih kecoklatan, P2 berwarna putih kekuningan, dan P3 berwarna coklat muda. Perbedaan warna dipengaruhi oleh jumlah inokulum dari masing-masing perlakuan. Perlakuan P3 memberikan perubahan warna paling nyata (gelap) dibandingkan dengan perlakuan P1 dan P2.

Perubahan warna yang terjadi pada tepung bulu ayam diduga sebagai akibat terjadinya browning (reaksi pencoklatan). Reaksi pencoklatan yang terjadi termasuk dalam jenis pencoklatan enzimatik. Bakteri-bakteri yang bekerja selama fermentasi menghasilkan enzim yang dapat mengkatalisis oksidasi dalam proses pencoklatan (Winarno, 2004). Jumlah inokulum yang digunakan dalam fermentasi akan meningkatkan konsentrasi enzim yang ada di dalamnya. Konsentrasi enzim yang tinggi akan meningkatkan proses katalisis oksidasi oleh enzim tersebut dalam proses pencoklatan. Selain itu, diduga dengan semakin tingginya konsentrasi enzim yang bekerja selama proses fermentasi akan menghasilkan kadar $\mathrm{NH}_{3}$ (amoniak) yang tinggi pula.

Hasil penelitian menunjukkan bahwa semakin banyak inokulum yang digunakan menghasilkan perubahan warna yang semakin nyata. Hal ini sesuai dengan pendapat Puastuti (2007) yang menyatakan bahwa pemrosesan tepung bulu ayam memberikan perubahan warna dari putih menjadi coklat akibat terjadinya reaksi browning (pencoklatan) yang ditandai juga dengan tingginya kadar $\mathrm{NH}_{3}$ yang dihasilkan.

\section{Tekstur}

Tekstur adalah keadaan fisik yang dapat dilihat dan diamati melalui panca indera. Tekstur dari suatu bahan menentukan kualitas bahan tersebut. Tepung bulu ayam yang tidak difermentasi memiliki tekstur yang liat, yaitu keras dan susah dihancurkan. Menurut Tarmizi (2001), bulu ayam merupakan salah satu produk pengerasan jaringan epidermal tubuh yang bersifat keras dan kaku. Tepung bulu ayam yang telah difermentasi memiliki tekstur yang berbeda dengan tepung bulu ayam yang tidak difermentasi, yaitu bertekstur lembut untuk perlakuan P1 dan P2 serta tekstur lembut dan remah untuk perlakuan $\mathrm{P} 3$.

Tekstur lembut pada tepung bulu ayam fermentasi diduga disebabkan karena terjadi perubahan sifat bahan pakan termasuk tekstur sebagai akibat dari pemecahan kandungan bahan pangan oleh mikroorganisme yang berada di dalamnya (Deliani, 2008). Adanya aktivitas enzim akan memecah ikatan yang ada pada protein, lipid, maupun amilase. Terurainya komponen-komponen tersebut membuat tekstur menjadi halus, lembut, dan remah.

\section{Bau}

Bau atau aroma bahan pakan dapat diuji menggunakan indera penciuman. Hasil uji organoleptik menunjukkan adanya perbedaan bau antara tepung bulu ayam non fermentasi dan yang difermentasi menggunakan $B$. subtilis. Tepung bulu ayam non fermentasi memiliki bau yang khas seperti bulu ayam yang telah kering (amis). Tepung bulu ayam yang telah difermentasi memiliki bau yang berbeda, yaitu berbau khas yang kurang menyengat untuk perlakuan P1. Pada perlakuan P2, tepung bulu ayam memiliki bau yang khas dan agak menyengat jika dibandingkan dengan perlakuan P1, sedangkan P3 memiliki bau yang khas dan sangat menyengat. Deliani (2008) menyatakan bahwa proses degradasi protein dapat menghasilkan antara lain polipeptida asam amino, pepton, unsur $\mathrm{N}$, dan komponen yang dapat menimbulkan bau busuk seperti $\mathrm{NH}_{3}$. Bau menyengat dapat dijadikan indikator kadar $\mathrm{NH}_{3}$ yang dihasilkan dalam proses fermentasi. Hasil uji terhadap bau tepung bulu ayam menunjukkan bahwa perlakuan P3 menghasilkan $\mathrm{NH}_{3}$ yang paling banyak. Tepung bulu ayam fermentasi menghasilkan bau yang berbeda dengan tepung bulu ayam non fermentasi disebabkan karena pengaruh kadar $\mathrm{NH}_{3}$ (amoniak) yang dihasilkan selama proses fermentasi

\section{KESIMPULAN}

Pemanfaatan limbah bulu ayam menjadi bahan pakan ikan dapat dilakukan dengan fermentasi Bacillus subtilis. Fermentasi tepung bulu ayam dengan $B$. subtilis dapat meningkatkan kualitas bahan baku pakan ikan. Perlakuan P2 dengan menggunakan inokulum $10 \mathrm{~mL} / 2 \mathrm{~g}$ tepung bulu ayam adalah perlakuan yang paling efektif karena menghasilkan protein tertinggi yaitu 80,59\%.

\section{UCAPAN TERIMAKASIH}

Penelitian ini merupakan bagian dari Penelitian Unggulan Perguruan Tinggi yang dibiayai oleh Ditjen Dikti. Oleh karena itu, penulis mengucapkan terima kasih kepada Ditjen Dikti yang telah membiayai penelitian ini, dengan No. Kontrak 018/K6/KL/SP/2013. 


\section{DAFTAR PUSTAKA}

Abubakar, Triyantini, Setyanto, H., Supriyati, Sugiarto, dan Wahyudi, M., 2000. Survey Potensi Ketersediaan Bulu Ayam, Cara Pengolahan dan Pemotongan Ternak Ayam di TPA. Laporan Penelitian T.A. 1999/2000. Balai Penelitian Ternak. Bogor.

Achmad, W., 2001. Potensi Limbah Agroindustri Sebagai Pakan Sapi Perah. Skripsi. Fakultas Peternakan, Institut Pertanian Bogor. Bogor.

Adiati, U., dan Puastuti, W., 2004. Bulu Ayam Untuk Pakan Ruminansia. Balai Peternakan. Bogor.

Agustono, Lokapirnasari, W.P., Setyono, H., dan Nurhajati, T., 2007. Pengantar Teknologi Pakan Ikan. Universitas Airlangga. Surabaya.

Anonim, 2012. Statistik Peternakan dan Kesehatan Hewan. CV. Alnindra Dunia Perkasa. Jakarta.

Brandelli, A., 2008. Bacterial Keratinases: Useful Enzymes for Bioprocessing Agroindustrial Wastes and Beyond. Food Bioprocess Technol, 1:105-116.

Deliani, 2008. Pengaruh Lama Fermentasi Terhadap Kadar Protein, Lemak, Komposisi Asam Lemak, dan Asam Fitat pada Pembuatan Tempe. Tesis. Sekolah Pascasarjana. Universitas Sumatera Utara. Medan.

Desi, M., 2002. Aktivitas Keratinase Bacillus licheniformis dalam Memecah Keratin Bulu Ayam. Skripsi. Fakultas Matematika dan Ilmu Pengetahuan Alam. Institut Pertanian Bogor. Bogor.

Imansyah, B., 2006. Mendaur Ulang Limbah Jadi Konsumsi Ternak. Tim Teknologi Informasi Peternakan. Fakultas Peternakan. Universitas Padjadjaran. Bandung.

Joshi. S. G., Tejashwini, M. M., Revati, N., Sridevi, R., dan Roma, D., 2007. Isolation, Identification and Characterization of Feather Degrading Bacterium. Department of Biotechnology. New Delhi.

Madigan, M.T., dan Martinko, J. M., 2005. Brock Biology of Microorganisms (11th ed.). Prentice Hall. New Jersey.

Maynard, L.A. Loosil, J.K., Hintz, H.F., dan Warner, R.G., 2005. Animal Nutrition (7th ed.). McGraw-Hill Book Company. New York.

Mazotto, A.M., Coelho, R.R., Cedrola, S.M., De Lima, M.F., Couri, S., de Paraguai, S.E., dan Vermelho, A.B., 2011. Keratinase Production by Three Bacillus sp. Using Feather Meal and Whole Feather as Substrate in a Submerged Fermentation. Research Article, Enzyme Research. Rio de Jenairo.

Mildayani, M., dan Haliza, W., 2007. Pengaruh Imbangan Ampas Tahu dan Onggok yang
Difermentasi dengan Ragi Oncom Terhadap Kandungan Zat Makanan. Skripsi. Fakultas Peternakan. Universitas Brawijaya. Malang.

Kim, W.K., dan Patterson, P.H., 2000. Nutritional Value of Enzyme or Sodium HydroxideTreated Feathers from Dead Hens. Journal of Poultry Science, 79:528-534.

Kumalasari, R., 2012. Pengaruh Konsentrasi Inokulum terhadap Kualitas Tempe Kedelai (Glycine max (L.) Merr) Var. Grobogan. Tugas Akhir. Fakultas Sains dan Matematika. Universitas Kristen Satya Wacana. Salatiga.

Periasamy, A.H., dan Subash, C.B.G., 2004. Keratinophilik Fungi of Poultry Fram and Father Dumping Soil In Tamil Nadu. University of Madras. Madras.

Puastuti, W., Yulistiani, D., dan Mathius, I.W., 2004. Bulu Ayam yang Diproses Secara Kimia Sebagai Sumber Protein Bypass Rumen. JITV, 9(2):73-80.

Puastuti, W., 2007. Teknologi Pemrosesan Bulu Ayam dan Pemanfaatannya Sebagai Sumber Protein Pakan Ruminansia. Wartazoa, (17)2:53-60.

Rodriguez, M.R., Valdivia, E., Soler, J.J. Vivaldi, M.M., Martin-Platero, A.M., dan MartinezBueno, M., 2009. Symbiotic Bacteria Living in the Hoopoe's Uropygial Gland Prevent Feather Degradation. J. Exp. Biol, 212:36213626.

Sa’adah, N., Hastuti, R., dan Prasetya, N.B.A., 2013. Pengaruh Asam Formiat pada Bulu Ayam Sebagai Adsorben Terhadap Penurunan Kadar Larutan Zat Warna Tekstil Remazon Golden Yellow RNL. Jurnal Kimia Universitas Diponegoro, 1(1):202-209.

Savitha, G. Joshi, M.M., Tejashwini, N., Revati, R., Sridevi, S., dan Roma, D., 2007. Isolation, Identification and Characterization of a Feather Degrading Bacterium. International Journal of Poultry Science, 6(9):689-693.

Sefrita, A., 2008. Pengaruh Dosis Inokulum dan Lama Fermentasi Tepung Bulu Ayam dengan Bakteri Bacillus coagulans Terhadap Kandungan Protein Kasar dan Aktivitas Enzim Keratinase. Skripsi. Fakultas Peternakan. Universitas Andalas. Padang.

Sinoy, S., Bhausaheb, T.C.P., dan Rajendra, P.P., 2011. Isolation and identification of feather degradable microorganism. VSRD-TNTJ, 2(3):128-136.

Sonjaya, T., 2001. Nilai Retensi Nitrogen dan Kandungan Energi Metabolis Tepung Bulu Ayam yang Mendapat Perlakuan Kimiawi, Biologis, dan Enzimatis. Skripsi. Jurusan Ilmu 
Nutrisi dan Makanan Ternak Fakultas Peternakan. Institut Pertanian Bogor. Bogor.

Suntornsuk, W., Tongjun, J., Onnim, P., Oyama, H., Ratanakanokchai, K., Kusamran, T., dan Oda, K., 2005. Purification and Characterisation of Keratinase from A Thermotolerant Feather Degrading Bacterium. World Jurnal of Microbiology \& Biotechnology. 21:11111117.

Suparjo, 2010. Evaluasi Pakan Secara In Sacco. www.jaja66.wordpress.com (Diakses 28 November 2013).

Supriyati, Purwadinata, T., dan Kompiang, I.P., 2000. Produksi Mikroba Terseleksi Pemecah Keratin pada Bulu Ayam Skala Laboratorium. Seminar Nasional Peternakan dan Veteriner 2000. Balai Penelitian Ternak. Bogor.

Suryono, Eddy. T, Joko. S., dan Ahmad. P., 2013. Teknologi Pengelolaan Limbah Produksi Pakan Ikan. Universitas Sebelas Maret. Surakarta.

Tarmizi, A., 2001. Evaluasi Nilai Nutrisi Tepung Bulu yang Difermentasi dengan Menggunakan Bacillus licheniformis pada Ayam Broiler. Skripsi. Jurusan Ilmu Nutrisi dan Makanan Ternak Fakultas Peternakan. Institut Pertanian Bogor. Bogor.

Tillman, A.D., Hartadi, H., Reksohadiprodjo, S., Prawirokusumo, S., dan Lebdosoekojo, S., 1998. Ilmu Makanan Ternak Dasar. Gadjah Mada University Press. Yogyakarta.

Tiwary, E., dan Gupta, R., 2012. Rapid Conversion of Chicken Feather to Feather Meal Using Dimeric Keratinase from Bacillus licheniformis ER-15. J. Bioproces Biotechniq. 2:4

Widodo, W., 2002. Bahan Pakan Konstekstual. Universitas Muhammadiyah Malang. Malang.

Winarno. F.G., 2004. Kimia Pangan dan Gizi. Edisi Terbaru. PT Gramedia Pustaka Utama. Jakarta.

Wulandari, Adi, W., dan Rahayu, S., 2013. Kecernaan Lemak dan Energi Konsentrat Monogastrik Berbasis Hidrolist Tepung Bulu Ayam secara In Vitro. Jurnal Ilmiah Peternakan, 1(2):430-436.

Zerdani, I., Faid, M., dan Malki. A,. 2004. Feather Wastes Digestion By New Isolated Strains Bacillus sp. Morocco African Journal of Biotechnology, 3(1):67-70. 